\title{
The Impact of Human Capital on Economic Growth: A case study of (Middle East and North Africa - excluding High income countries)
}

\author{
Khalil Ghazi Hassan
}

Department of Economic, College of Administration and Economics, University of Duhok. Kurdistan Region, Iraq

\begin{abstract}
The study aims at estimating and analyzing the impact of human capital investments in economic growth in (Middle east and north Africa (excluding High income countries) for the period (1990-2018) to test the hypothesis that investment spending on the development of the human resource has a positive effect on economic growth. A long run cointegration relationship between the variables has been found, the results indicate that all of the explanatory variables are statistically significant at the $5 \%$ level or less, but while the impact of (EMP, SES, SET, GCFG) is positive, it was found that (SEP) has a negative effect in economic growth.so providing schools that fail to teach basic skills does no promote output growth. So, providing schools that fail to teach basic skills does no promote output growth. Therefore, slowing the pace of the provision of schools to a rate that also permits the development of quality learning appears to be a best choice for a good solution. So, providing schools that fail to teach basic skills does no promote output growth. Therefore, slowing the pace of the provision of schools to a rate that also permits the development of quality learning appears to be a best choice for a good solution.
\end{abstract}

\section{Introduction}

Mainly, the human capital is one of the most significant keys to the production process, which aims to achieve the necessary increases in growth rates to ensure access to development levels consistent with the planned economic and social goals. Yet the evidence is quite strong of the close link between Investments in human capital and economic growth, since human capital embodied knowledge and skills, while the process of economic development requires appropriate rates of economic growth, it also requires increased productivity of elements. In turn, investment in human capital will be imperative to ensure sustainable growth (Qaiser \& Foreman,2008).

In an attempt to answer the question about the effectiveness of human capital as a component of economic growth, the study aims to test the hypothesis that human capital has a positive effect on economic growth.

This paper models the impact of human capital variables on the economic growth of countries group classified by
World Bank database as (Middle east and north African Countries (excluding High-income countries) for the period 1990-2018. For this purpose, a conceptual framework for human capital will be presented, then theoretical treatments will be discussed and previous relevant studies will be reviewed, followed by the presentation of the theoretical and applied treatment mechanism for the study issue and the final presentation of discussion of the results.

2. The human capital: definitions, conceptual framework

Human capital is a reference to knowledge, skills, behavior, attitudes, talent, and any other feature necessary for the production process (un,2016). This is a broader concept of education because it includes any productive skills or individual abilities. In other words, it includes all forms of investment aimed at improving and developing the skills of individuals such as school education, non-formal education, job learning and learning by working. It also includes factors that 
facilitate the productive use of human skills such as health (Ali et el,2018).

In internal growth literature, knowledge embodied in individuals is called human capital and assumed to be very important if not the most important source that explains most of the changes in economic growth (Romer Mankiw,1990- Aghion \& Howitt, 1992). The accumulation of knowledge creates new ideas and improves both productivity and product quality. At the macro level, greater human capital encourages entrepreneurship and innovation that lead to higher economic growth rates (Dakhli \& Clercq, 2004). The concept was recently expanded to include the sum of innate abilities, knowledge, and skills acquired by individuals and developed during their lifetime (Mireille Laroche,1998).

Adam Smith first implicitly referred to human capital in his definition of capital. The capital stock included nations, people, and talents because the skill of individuals increased the wealth of society and individuals(un,2016). The idea of human capital was forgotten for a long time until it was revived in 1958 by (Schultz,1961) and Becker (Becker,1992), linking it to economic growth and highlighting its role in interpreting differences in returns. During the same period, the development of the neoclassical growth theory of Solo and Swan failed to present a formula or scheme that illustrates the role of human capital as an engine of economic growth.

Such a scheme became available later in the partial contributions of Romer in1986 (Romer,1992) and Lucas in 1988(Robert Lucas,2015) and the emergence of internal growth theory literature that stimulated the curiosity of economists in examining the role of human capital as a determinant of economic growth. These models suggest that human capital stimulates growth by stimulating technological development and improving productivity. Recent empirical studies on economic growth suggest that the skills and knowledge of the country's population are important in determining their economic performance.

Internal growth literature emerged as technological developments made changes and endless changes in production methods and processes. These changes have transformed industrialized countries into knowledgedriven economies. Moving from a resource-based economy to a knowledge-based economy has made human capital the central pillar of government policy (Brinkley,2006). But its definitions and characterization as a variable and its measurements in quantitative models lost their most important elements.

\section{Human capital; measurements}

As human capital is intangible and difficult to quantify, its measurement remains a challenge to researchers and its understanding and quantification are increasingly necessary for policymakers to accurately define the elements of economic growth, assess the long-term sustainability of the development path, and measure product performance and productivity. But the idea was accepted and debated by a scientific complaint that began in the 1960s, partly reflecting the view that the concept of human capital can explain the large difference between an increase in a country's economic output and traditional inputs (land, labor, and capital). Schultze saw investment in human capital as perhaps the main explanation for this difference (Shultze, 1961), which defined human capital as "acquired skills and knowledge" to distinguish unskilled labor from skilled labor. Human capital investment offers many other noneconomic benefits as well, such as improved health and personal well-being, many researchers view these benefits as important, If not larger, of economic benefits in the form of higher returns and economic growth.

Accordingly, the Organization for Economic Co- 
operation and Development (OECD) gradually sought to define human capital. In a subsequent report, human capital was defined as "the knowledge, skills, competencies and personality traits of individuals that facilitate the creation of personal, social and economic well-being", A number of methods have been used to measure human capital, including direct and indirect methods. Direct approaches draw a measure of human capital stock from information on its various components. There are three direct ways to measure human capital (OECD,2009- Gibson J. et el,2008):

i. Cost-based approach - This approach is based on information on all the costs that are incurred when producing human capital. The indicators needed to calculate the human capital index are (population distribution by age, gender, and level of education, average years of schooling by the level of education.

ii. 2. The income-based approach during the life cycle Unlike the cost-based approach, which focuses on the input side, the lifetime income-based approach measures the balance of human capital by output (although the output in this way is limited to special cash benefits which belong to the person in which human capital is embodied). The data needed to measure the indicator are population and educational attainment, student and school population, duration of school stay, labor force and employment, labor income and survival rates.

iii. 3. Indicator-based approach - Human capital assessment based on indicators of educational outcomes. Numerous measures have been used in literature - for example, adult literacy; enrollment rates; average school years (Barro-Lee 2010). Unlike other indicators, this approach relies on many indicators that, although informative, lack a common yardstick.

iv. What hinders the calculation of the balance of human capital and its contribution to economic growth is the inability of the national and government accounts to measure investments and savings and to correctly classify government expenditures in the context of the knowledge economy. (Jorgenson \& Fraumeni, 1994) showed that during the period 1948-1984, investment in human capital was always three times the material investment in the United States. During the same period, the value of human capital became more than nine times the physical capital, human capital from national accounts reduces the value of investments and wealth in the economy. Moreover, recent empirical studies of growth attempted to add the role of human capital as a determinant of longterm economic achievement using other measures of human capital (e.g. enrollment rates, Barro, 1991), literacy rates (Romer, 1989), education outcomes (Koman \& Marin, 1997). These standards are constrained by the availability of data and always lose some of the human capital allocations.

\section{Theoretical Framework and Literature Review}

Solow (1956) observed that the Harrod-Domar model, whose economy fluctuates between unemployment and inflation, is derived from the assumption that the capitaloutput coefficient is constant. Therefore, he assumed the substitution between the elements of production and substituted the capital-fixed output in a linear homogeneous equation (Solow,1956). Thus, human capital can be added as an additional variable to the Solow model, and it is considered an internal variable that has a direct effect on production. The theoretical formulas of the relationship between human capital and economic growth suggest that the knowledge embodied in human resource is very important for innovation, productivity, and growth (Romer, 1990). This relationship is not always correct, Some empirical 
studies have not given definitive evidence, e.g. (Benhabib \& Spiegel, et el,1994) found that there is a positive relationship between the current level of human capital of an economy and the rate of per capita income, but the growth of human capital has no significant impact on the growth of per capita income. In fact, the level of human capital found to have a positive correlation with economic growth seems to be due to issues related to the characterization of the human capital variable (Ali et el, 2018). (Hanushek \& Kimko,2000) emphasized the element of education and others emphasized the importance of inflation, health, and the opportunity cost of investment. (Becker, 1994, Barro, 2001) focused on the role of education and distinguished between the amounts of education measured by years of academic achievement. The expanded classical model was adopted for the same scholar in 1997, using data from 100 countries for the period 1965-1995. It was found that growth was positively correlated with the first level for years of educational achievement of both sexes in both the preparatory and higher levels. As workers have an educational background from the different stages, they allow them to acquire the technical knowledge that allows them to play an important role in the process of economic growth.

Fernandez \& Mauro (2000) prepared an index or measure of human capital for 1977-1997 in Spain and applied it to the period (2000-2010). Using the production function model $\mathrm{Y}=\mathrm{A} * \mathrm{~F}(\mathrm{~K}, \mathrm{~L})$, Economic growth has been large and gradually increasing in the last two decades, which suggests that it will contribute to growth in the coming years using the time series data for Pakistan for the period 1978-2007 for human capital expressed in the Cop- Douglas, and show a positive relationship between human capital and economic growth in the long term, and this is what the results of the previous empirical studies also indicate that the relationship between them is significant and strong (Fernandez \& Mauro, 2000).

(Qadri \& Waheed, 2011), estimated the relationship between human capital and economic growth using total time series data and the Johansen approach (1991). The estimated results indicate that the role of human capital is important in enhancing the economy's ability to absorb global technological development, shows that health spending returns are higher than industrial investment returns on economic growth.

The study of (Pelinescu, 2015) highlighted the importance of human capital in ensuring GDP growth and per capita share. The results showed a positive and moral relationship between per capita GDP and renewable capacities in human capital, measured by (number of patents, and there was an unexpected inverse relation between expenditure on education as a percentage of GDP and per capita share. This was explained by the heterogeneity of the countries in the sample.

(Wang \& Shasha,2016). Using the latest available data for 55 countries and territories for the period 1960-2009, and by dividing human capital education into higher, secondary, and primary education, the impact of different levels of education Economic growth. In addition, the health index was tested. It was found that the effect of higher education was significant while the effect of secondary and primary education was not. There was also a significant and positive relationship between life expectancy and per capita GDP.

The impact of human capital on economic growth in the short and long term was tested using Johansen's cointegration for the period 1970-2013 (Hakoma \& Sehamani 2017). The results showed a long-term common economic integration relationship between economic growth (expressed in per capita GDP) and 
human capital expressed in government expenditure on health, education and secondary education. The longterm model estimates that the health variable expressed in government expenditure on health was the largest contributor to growth, followed by the education index expressed by the number of students enrolled in secondary education. These results are consistent with the results of internal growth models that improve human capital in the form of skillful and healthy workers improve productivity.

Bobetko, examined the relationship between human capital and economic growth using cross-section data from a sample of 25 emerging market countries for the period 1995-2015. In the absence of a consensus agreement on an appropriate agreed index, different or multiple indicators were used in the model. A positive relationship between the two variables was found when human capital is measured by acquired skills (cognitive). The duration of education was also statistically significant (Bobetko,et el,2017).

\section{The Methodology of Assessment}

The standard methodology for the relationship between growth and human capital is the determinant of a total production function where $\mathrm{Y}$ is the dependent variable and the introduction of three factors, namely labor force Lt, physical capital Kt, and human capital Ht are the independent variables. As follows (Qaiser, 2000:

$Y t=A t K t \backslash a \operatorname{Lt} \beta$ Ht et ...

Where At $=$ the externally defined technology level, $\mathrm{Kt}=$ total domestic investment (an alternative or approximation of physical capital), Lt $=$ Labor and et $=$ error limit.

In light of the Lucas model, an econometric model was built to investigate the relationship between human capital and economic growth. An econometric model of the selected variables used in this study is given as follows(Syed \& Ali Shah,2015:

\section{$\mathrm{EG}=\beta_{0}+\beta_{1} \mathrm{GCF}+\beta_{2} \mathrm{EMP}+\beta_{3} \mathrm{SEP}+\beta_{4} \mathrm{SES}+\beta_{5} \mathrm{SET}+$ $\mathrm{U}_{\mathrm{t} . . .(2)}$}

Where:

$\mathrm{EG}=$ annual growth rate of GDP

$\mathrm{GCF}=$ annual growth rate of Gross capital formation

$\mathrm{EMP}=$ Employment rate (an alternative or approximation of labor)

SEP, SES, SET: the rate of school enrollment in primary, secondary and tertiary levels of education (an alternative or approximations of human capital variables, this is because of data constraints, alternative variables related to calculated growth are used that are directly observable. For example, data on school education were selected as the proximate alternative to a human capital variable, taking enrollment rates at different levels of education.

\section{Empirical Results}

Theoretically, economic analysis suggests that time series were stationary or at least stationary around a deterministic trend and as well exhibited a long-run relationship.

A recent development in econometrics has however, revealed that often times, most time series is not stationary as was conventionally thought. Therefore, different time series may not display the same features (Emeka,2016).

In dealing with time-series data, it was important to test for a unit root in order to know the order of integration of each series as well know the number of times series must be differenced to attain stationarity. To overcome this problem of non-stationarity and prior restrictions on the lag structure of a model, econometric analysis of time series data has increasingly moved towards the issue of cointegration for detecting the presence of steady-state equilibrium between variables In this quest, the augmented Dickey-Fuller (ADF) and the Phillips-Perron (PP) unit root tests are utilized. The PP test was adopted 
to deal with the rather restrictive assumption of the ADF. the next step was to test for the existence of a long-run relationship between the variables. The study, therefore, adopted the ARDL cointegration test approach.

\subsection{Unit root tests:}

The traditional Augmented Dickey Fuller and Phillips Perron unit root test is usually used to check the stationarity of time series variables., the results of the ADF and PP tests are presented in Table 4.1.1

Table 4.1.1

ADF and PP Test Results (LIG)

\begin{tabular}{cccccccc}
\hline \hline & & \multicolumn{2}{c}{ Augmented Dickey-Fuller } & \multicolumn{3}{c}{ Phillips-Perron } \\
\cline { 3 - 8 } $\begin{array}{c}\text { Order of } \\
\text { integration }\end{array}$ & variables & intercept $\begin{array}{c}\text { Trend } \\
\text { and } \\
\text { intercept }\end{array}$ & None & intercept & $\begin{array}{c}\text { Trend and } \\
\text { intercept }\end{array}$ & None \\
\hline $\begin{array}{c}\text { Level } \\
\text { Level }\end{array}$ & EG & $-8.459696^{*}$ & $-8.21490^{*}$ & $-3.60499^{*}$ & $-7.60263^{*}$ & $-7.432865^{*}$ & $--3.718233^{*}$ \\
$1^{\text {st }}$ & EMP & -1.695987 & 1.760996 & -1.022883 & -1.865011 & -1.985688 & -0.947306 \\
difference & EMP & $-4.872223^{*}$ & $-4.78653^{*}$ & $-4.791598^{*}$ & $-4.87222^{*}$ & $-4.78653^{*}$ & $-4.791560^{*}$ \\
$\begin{array}{c}\text { Level } \\
\text { Level }\end{array}$ & GCFG & $-4.897106^{*}$ & $-4.82979^{*}$ & $-3.842378^{*}$ & $-3.27948^{* *}$ & $-3.44814^{* * *}$ & $-3.068843^{*}$ \\
$1^{\text {st }}$ & SEP & -0.824138 & -1.325148 & 1.448307 & -0.794819 & -1.271292 & -1.56861 \\
difference & SEP & $-5.793057^{*}$ & $-5.68472^{*}$ & $-5.47131^{*}$ & $-5.77849^{*}$ & $-5.674065^{*}$ & $-5.463490^{*}$ \\
$\begin{array}{c}\text { Level } \\
1^{\text {st }}\end{array}$ & SES & -1.464147 & -1.595927 & +3.391999 & -1.445844 & --1.730737 & +3.194149 \\
difference & SES & $4.503966^{*}$ & $-4.67630^{*}$ & $-3.354061^{*}$ & $-4.50397^{*}$ & $-4.676304^{*}$ & $-3.354061^{*}$ \\
$\begin{array}{c}\text { Level } \\
1^{\text {st }}\end{array}$ & SET & +0.074131 & -1.634144 & +2.651952 & +0.80752 & -1.939390 & $+6.20162^{*}$ \\
difference & SET & $-4.025872^{*}$ & $-3.82683^{* * *}$ & -1.894909 & $-4.02587^{*}$ & $--3.82684^{* *}$ & -1.894909 \\
\hline \hline$* * * * * *$ \\
$*$
\end{tabular}

Table 1 reports the tests results using both methods which are conducted with the trend, intercept and none. The unit root tests confirm that the dependent variable EG and the explanatory variables (GFCG, EMP SEP, SES, SET), are not stable at different orders; whereas (EG) is stable at the level, the (GFCG, EMP, SEP, SES, SET) are stable at first difference at the $5 \%$ significance level or lower.

\subsection{Cointegration Test}

Testing for cointegration is a necessary step to establish if a model empirically exhibits meaningful long-run relationships. If it failed to establish the cointegration among underlying variables, it becomes imperative to continue to work with variables in differences instead. However, long-run information will be missing. There are several tests of cointegration, other than Engle and Granger (1987) procedure, among them is; Autoregressive Distributed Lag cointegration technique or bound cointegration testing technique.

Irrespective of whether the underlying variables are I(0) or I(1) or a combination of both, ARDL technique can be applied. This means that the bound cointegration testing procedure does not require the pre-testing of the variables included in the model for unit roots and is robust when there is a single long-run relationship between the underlying variables.

\subsection{The preliminary estimation of the ARDL model:}

Table (4.2) shows that the model is significant as a whole through the F test, and, the value of the adjusted R2 coefficient $(\mathrm{R}-2=57.5 \%)$ which gives the explanatory power for the model.

Table 4.4

Preliminary Estimation of the ARDL

\begin{tabular}{|l|c|c|c|}
\hline Estimators & Coefficients & Estimators & Coefficients \\
\hline R-squared & 0.685011 & $\begin{array}{c}\text { Mean } \\
\text { dependent var }\end{array}$ & 3.537117 \\
\hline $\begin{array}{l}\text { Adjusted R- } \\
\text { squared }\end{array}$ & 0.574765 & $\begin{array}{c}\text { S.D. } \\
\text { dependent var }\end{array}$ & 2.250775 \\
\hline $\begin{array}{l}\text { S.E. of } \\
\text { regression }\end{array}$ & 1.467731 & $\begin{array}{c}\text { Akaike info } \\
\text { criterion }\end{array}$ & 3.840269 \\
\hline $\begin{array}{l}\text { Sum squared } \\
\text { resid }\end{array}$ & 43.08470 & $\begin{array}{c}\text { Schwarz } \\
\text { criterion }\end{array}$ & 4.220899 \\
\hline $\begin{array}{l}\text { Log } \\
\text { likelihood }\end{array}$ & -45.76377 & $\begin{array}{c}\text { Hannan- } \\
\text { Quinn criter. }\end{array}$ & 3.956631 \\
\hline F-statistic & 6.213474 & $\begin{array}{c}\text { Durbin- } \\
\text { Watson stat }\end{array}$ & 2.409191 \\
\hline $\begin{array}{l}\text { Prob(F- } \\
\text { statistic) }\end{array}$ & 0.000588 & \multicolumn{2}{|l}{} \\
\hline
\end{tabular}

Source: Eviews; Authors calculation

\subsection{Bound Test}

This Approach for Cointegration test is a statistical property of time series variables. Two or more time series are cointegrated if they share a common stochastic drift. In other words, if there exists a stationary linear combination of non-stationary random variables, the variables combined are said to be cointegrated. ARDL long run form and bound test result are showed in the table (6.4) below: 


\begin{tabular}{|c|c|c|}
\hline & esult & \\
\hline \multirow{3}{*}{ Critical values } & \multicolumn{2}{|c|}{ F. Statistic } \\
\hline & \multicolumn{2}{|c|}{27.32986} \\
\hline & $1(0)$ & $1(1)$ \\
\hline $10 \%$ & 2.08 & 3 \\
\hline $5 \%$ & 2.39 & 3.38 \\
\hline $2.5 \%$ & 2.7 & 3.73 \\
\hline $1 \%$ & 3.06 & 4.15 \\
\hline
\end{tabular}

Source: Eviews; Authors calculation

In table (6.4) it is noticed that the statistical value $(\mathrm{F})$ is (27.32986), which is greater than the maximum critical values at the level of $(1 \%)$ which equals (4.15), this means acceptance of the alternative hypothesis that there is a long-run equilibrium relationship between the dependent and explanatory variables for the duration period.

\subsection{Estimation of long-run and short-run relationship}

\subsubsection{Long-run relationship:}

In Table (4.6), there is a long-run response between (EGH) and (EMP, SEP, SES, SET, GCFG). Here the longand short-run results are consistent with the assumption in the model that the parameters independent variables have a significant effect on the annual rate of GDP growth (EG).

From the Long-run estimates for the ARDL Model, we note the positive and significant impact of (EMP, SES, SET, GCFG) on economic growth rates, where the increase of them by $1 \%$ leads to increase economic growth rates by accompanying rates, Note that the (SEP) parameter is statistically significant, at less than $5 \%$, but with negative sign That is, we reject the null hypothesis and say that the parameters are statistically significant at $5 \%$ level. The explanation for this relationship is that (EMP, SEP, SES, SET, GCFG) positively affect economic growth and contribute to increasing its rates.

Table 6.5.1

Long-run estimates for the ARDL Model

\begin{tabular}{lcccc}
\hline \multicolumn{5}{c}{ Long Run Coefficients } \\
\hline Variable & Coefficient & Std - Error & T-Statistic & Prob. \\
EMP & 4.931841 & 0.861788 & 5.722801 & 0.0000 \\
GCFG & 0.077390 & 0.023072 & 3.354330 & 0.0032 \\
SEP & -1.060080 & 0.207387 & -5.111601 & 0.0001 \\
SES & 0.538318 & 0.143647 & 3.747515 & 0.0013 \\
SET & 0.203528 & 0.080818 & 2.518353 & 0.0204 \\
C & -130.6508 & 25.34897 & -5.154086 & 0.0000 \\
\hline \hline Source: Eviews; Authors calculation
\end{tabular}

\subsubsection{Short Run Relationship}

Table (6.5.2) shows that, whereas all of the explanatory variable are statistically significant at the $5 \%$ level, the impact of (EMP, SES, SET, GCFG) on the growth rate in the short- run is positive and significant at the $5 \%$ level or less, but (SEP) with one lag has a significant but negative effect.

The results of the error correction model showed that the error correction slowdown coefficient reveals the speed (or slow) of the variables returning to the equilibrium state, the negative signal shows the short-run dynamic model convergence and the negative and moral coefficient associated with slowing the error correction limit, is more effective way of demonstrating cointegration. In this model, the value of the error correction coefficient CointEq (-1), which means the error correction speed, is negative and is about (-1.524970) and we note that it has a strong statistical significance at the level of $0.000 \%$, which increases the accuracy and validity of the equilibrium relationship in the long run, which means the error correction speed, is negative and is about (-1.524970), and we note that it has a strong statistical significance at the level of $0.000 \%$, which increases the accuracy and validity of the equilibrium relationship in the long run, It also indicates that the growth rate in one slow period reached $(-1.524970)$ with a negative signal and a probability of 0.000 , which means that the annual growth rate passes shocks in the short term by $(-1.524970)$ years, that is, the growth rate is due to its long-term equilibrium over a period of (2.5) years 
and passes Full shocks in the short term.

Table 6.5.2

Short-run Estimates for the ARDL Model

\begin{tabular}{|c|c|c|c|c|}
\hline \multicolumn{5}{|c|}{ L" Long Run Coefficients } \\
\hline Variable & Coefficient & Std - Error & T-Statistic & Prob. \\
\hline $\mathrm{C}$ & -199.2385 & 40.50248 & -4.919167 & 0.0001 \\
\hline $\mathrm{EG}(-1)^{*}$ & -1.524970 & 0.115390 & -13.21579 & 0.0000 \\
\hline $\mathrm{EMP}^{* *}$ & 7.520908 & 1.384014 & 5.434128 & 0.0000 \\
\hline $\mathrm{GCFG}^{* *}$ & 0.118017 & 0.036053 & 3.273410 & 0.0038 \\
\hline SEP(-1) & -1.616590 & 0.318535 & -5.075073 & 0.0001 \\
\hline SES** & 0.820918 & 0.213044 & 3.853270 & 0.0010 \\
\hline $\mathrm{SET}^{* *}$ & 0.310374 & 0.126591 & 2.451791 & 0.0235 \\
\hline $\mathrm{D}(\mathrm{SEP})$ & -0.606462 & 0.353415 & -1.716006 & 0.1016 \\
\hline
\end{tabular}

Source: Eviews; Authors calculation

\subsubsection{Structural stability tests of estimated Models}

A cumulative sum control chart (CUSUM) test is utilized for the absence of any structural changes in the data used. The critical level at (5\%), confirms that the variables are stable. Figure (1) translates the static long and short-run parameters of the model, which indicates stability between the variables studied phenomenon because they are all within the limits of confidence during the study period. The

graph shows that the total cumulative sum control chart CUSUM remaining for this pattern is an average line within the boundaries of the critical region, indicating the stability of the pattern at a large $5 \%$ boundary. Furthermore the cumulative sum of the squares of the residuals (CUSUM of Squares) Figure (2), also represents an average line within the boundaries of the critical area.

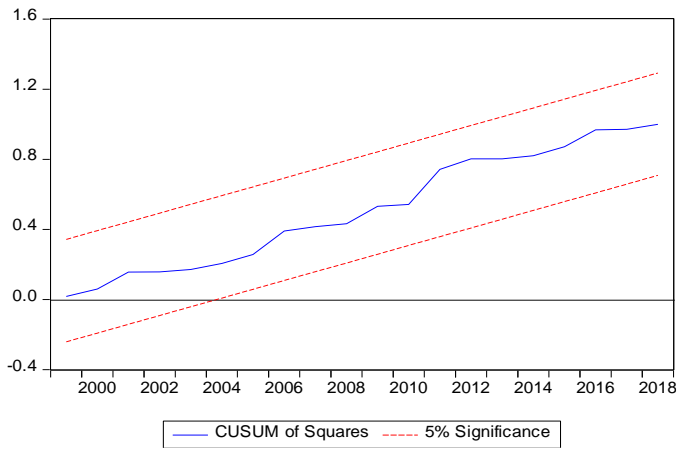

Figure 1.

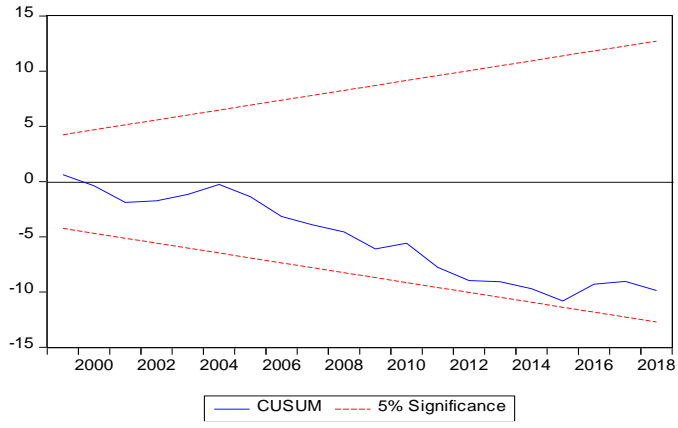

Figure 2.

\subsubsection{Diagnostics tests:}

Here we will test for both serial correlation and Heteroscedasticity between the errors.

For testing the hypothesis of non-correlation of errors, we use a serial-correlation test (Breusch-Godfrey Serial Correlation). Hence table(4.8) shows that Lagrange multiplier $\mathrm{LM}<\chi^{2}$ and probability values are not significant at $5 \%$, this indicate that there is no subjective correlation for the remainder of the estimated model , and we then reject the Null Hypothesis of being their a serial correlation between the errors.

Table 4.8

Breusch-Godfrey Serial Correlation outputs

\begin{tabular}{lcll}
\hline \hline \multicolumn{4}{c}{ Breusch-Godfrey Serial Correlation } \\
\hline F-statistic & 2.425579 & Prob. F (2,25) & 0.1168 \\
Obs*R-squared & & Prob. Chi- & \\
& 5.944225 & Square (2) & 0.0512 \\
\hline \hline
\end{tabular}

Source: Eviews; Authors calculation

There are several tests to detect that the residuals are homogeneous or not, among them the ARCH test. It was found that the model does not suffer from the problem of Heteroscedasticity, while the value of $\mathrm{LM}<\chi^{2}$ and the probability values are not significant at $5 \%$, and this indicates the Homoscedasticity of the residuals estimated, as shown in the table (4.9) below:

Table 4.9

Heteroskedasticity Test: ARCH

\begin{tabular}{lclc}
\hline \hline \multicolumn{3}{c}{ Heteroscedasticity Test: ARCH } \\
\hline F-statistic & 0.057013 & Prob. F $(1,33)$ & 0.8132 \\
Obs*R-squared & & Prob. Chi- & \\
& 0.061434 & Square (1) & 0.8042 \\
\hline \hline Source: Eviews; Authors calculation
\end{tabular}

Source: Eviews; Authors calculation 


\section{Conclusions}

The aim of the study is to investigate the relationship between human capital and economic growth (Middle east and north Africa (excluding High-income countries). For this purpose, the main questions that are how the human capital impact on the economic growth in mentioned countries.

This paper highlighted the importance of human capital in ensuring economic growth expressed as the annual growth rate (EG). The model revealed a positive relationship, statistically significant between (EG) and human capital (evidenced by the rates of school enrollment).

There are some important explanatory variables used in this model to verify the relationship between human capital and economic growth such as Annual growth rate of gross capital formation, employment rates, gross school enrollment rates in (primary, secondary and tertiary stages).

Whereas the cointegration test shows the presence of long-run cointegration between the variables, the results indicate that all of the explanatory variables are statistically significant at the 5\% level, but while the impact of (EMP, SES, SET, GCFG) on the growth rate in the short and long run is positive and, it was founded that (SEP) with one lag has a significant but negative effect on economic growth, This means that primary education may not help the workforce to acquire the necessary skills that qualify them to contribute to increased productivity or economic growth. Vice versa the secondary and tertiary education.

However, the evidence from the analysis of the growth model indicates that providing schools that fail to teach basic skills does no promote output growth. Therefore, slowing the pace of the provision of schools to a rate that also permits the development of quality learning appears to be a best choice for a good solution.

\section{References}

1. Ali et el, Human Capital, Social Capabilities and Economic Growth, MDPI Journal,6:2,2018,2-18.

2. Barro r. \& Jong lee, A new data set of educational attainment in the World 1950-2010, NBER working papers, JEL No. F43, I21, O11, O4, April 2010,2-49.

3. Barro R., Human Capital and Growth, The American Economic Review, Vol. 91, No. 2, (May, 2001), pp. 12-17.

4. Becker Gary S., Human Capital and the Economy, proceedings of the American Philosophical Society, Vol. 136, No. 1 (Mar., 1992), pp.85-92., Human Capital and the Economy, proceedings of the American Philosophical Society, Vol. 136, No. 1 (Mar., 1992), pp.85-92.

5. Benhabib J.\& Spiegel M., The role of human capital in economic development

6. Evidence from aggregate cross-country data, Journal of Monetary Economics 34 (1994) 143-173.

7. Bobetko A. et el, Human Capital and Economic Growth in CEE Countries and Other Emerging Markets, Twenty third Dubrovnik Economic Conference, Croatia, June 4 6, 2017, 2-19.

8. Brinkley I., Defining the knowledge economy, Knowledge economy programme report, first published July 2006, ibrinkley@theworkfoundation.com

9. Dakhli M.\& clercq D., Human Capital, Social Capital and Innovation: A Multi-Country Study, Institute of International Business; J. Mack Robinson College of Business;D.DeClercq@ugent.be or Dirk.DeClercq@vlerick.be, 2003,1-37.

10. Emeka N.\& Uko A., Autoregressive Distributed Lag (ARDL) cointegration technique: application and interpretation, Journal of Statistical and Econometric Methods, vol.5, no.4, 2016, 63-91.

11. Hakoma M.\& Sheshamani V., the impact of human capital on economic growth in Zambia, An econometric analysis, International Journal of Economics, Commerce and Management, Vol. V, Issue 4, April 2017.

12. Hanushek \& Kimko, Schooling, Labor-Force Quality, and the Growth of Nations, The American Economic Review, Vol. 90, No. 5 (Dec., 2000), pp. 1184-1208.

13. Hong L.T.\& Stinson T., An Alternative Measure of the Human Capital Stock, Economic Development center, Bulletin Number 97-1, April 1997.

14. John G. et el, Measuring Human capital: Alternative methods and International evidence, The Korean Economic Review, Volume 24, Number 2, Winter 2008

15. Jorgenson D. \& Fraumeni B., The Accumulation of Human and Nonhuman Capital,1948 -84, University of Chicago Press, 1989, 230-232.

16. Lucas R., Human Capital and Growth, The American Economic Review, Vol. 105, No. 5, (MAY 2015), pp. 85-88.

17. Mankiw G. et el, A Contribution to the empirics of economic growth, NBER working papers,1990.

18. Mireille L. et el, On the Concept and Dimensions of 
Human Capital in a Knowledge-Based Economy Context, Canadian Public Policy / Analyse de Politiques, Vol. 25, No. 1 (Mar., 1999), pp. 87-100.

19. OECD, Human capital and its Measurement, The 3rd OECD World Forum on "Statistics, Knowledge and Policy, Busan, Korea - 27-30 October 2009.4-15.

20. Paulo M. \& Fernandez E., The role of human capital in economic growth: the case of Spain, IMF working papers,2000.

21. Pelinescu E. The impact of human capital on economic growth, Procedia Economics and Finance 22 (2015) 184 190.

22. Philip A. \& Howit Peter, A Model of Growth Through Creative Destruction." Econometrica 60, no. 2: 323-351.

23. Qadri F.\& Waheed A., Human Capital and Economic Growth: Time Series Evidence from Pakistan, Business review, January 2011,3-18.

24. Qaiser A. \& Foreman J., Human Capital and Economic Growth: Pakistan, 1960-2003, The Lahore Journal of Economics13: 1 (Summer 2008): pp. 1-27.

25. .Qaiser A., The Role of Human Capital in Economic Growth: A Comparative Study of Pakistan and India, The Pakistan Development Review 39: 4 Part II (Winter 2000) pp. 451-473.

26. Romer p., The Origins of Endogenous Growth, Journal of Economic Perspectives-Volume 8, Number 1-Winter 1994-PP3-22.

27. Solow R. M., "A Contribution to the Theory of Economic Growth" the Quarterly Journal of Economics, Vol. 70, No. 1 (Feb., 1956), pp. 65-94

28. Schultz T., Investment in Human Capital, The American Economic Review, Vol. 51, No. 1 (Mar., 1961), pp. 1-17.

29. Syed W. \& Ali Shah, Human Capital and Economic Growth: Evidence from

30. Selected Asian Countries, Journal of Resources Development and Management, Vol.11, 2015.

31. UN, United Nations Economic Commission for Europe, Guide on Measuring Human Capital, Newyourk,

32. Wang Y. \& Shasha L., Education, Human Capital and Economic Growth: Empirical Research on 55 Countries and Regions (1960-2009), Theoretical Economics Letters, 2016, 6, 347-355. 